\title{
THE EFFECTS OF ENVIRONMENTAL, SOCIAL AND GOVERNANCE ON THE CORPORATE PERFORMANCE OF MALAYSIAN GOVERNMENT- LINKED COMPANIES
}

\author{
Qian Long Kweh*, Bakhtiar Alrazi, Yee Chuann Chan, Wan Mohammad Taufik Wan Abdullah \\ Department of Accounting, Universiti Tenaga Nasional, Pahang, Malaysia
}

\begin{abstract}
This study examines the impacts of ESG on the corporate performance government-linked companies (GLCs) in Malaysia. For the period 2006-2012, ESG disclosure data were extracted from the Sustainalytics ESG performance reports, while financial data were obtained from the Bloomberg database. Data development analysis (DEA) was used to estimate efficiency in the first stage; a regression analysis was performed to test the relationship between ESG and efficiency in the second stage. The empirical results of this study show that GLCs focused more on governance disclosures, followed by social and environmental aspects. Moreover, governance will improve firm efficiency, but social and environmental factors have no similar effect. In conclusion, this study provides insight on the limited literature on ESG and informs the relevant stakeholders on the important ESG components for financial and investment decisions.
\end{abstract}

Keywords: Environmental, Social and Governance (ESG), firm efficiency, data envelopment analysis, government-linked companies

\section{INTRODUCTION}

Environmental, Social and Governance (ESG) information is getting gradually more included into corporate communication (Arvidsson, 2010; Ihlen, 2008). ESG can also be known as "extrafinancial' information that help investors make investment decision by better assessments of risks and opportunities (Bassen \& Kovacs, 2008). Prior studies (for example, Bachoo, Tan, \& Wilson, 2013; Bebchuk, Cohen, \& Wang, 2013; Clark, Feiner, \& Viehs, 2015; Servaes \& Tamayo, 2013; Wang, Lu, Kweh, \& Lai, 2014) have extensively examined the effects of ESG on corporate performance; however, the results have been mixed and thus inconclusive.

The open debate could be due to the inconclusive findings and weaknesses in the measure of firm performance. To elaborate, single-dimensional measures of corporate performance used in the prior studies include return on assets (ROA) that are subject to interpretation and thus may not be sufficient for performance measurement (Feroz, Kim, \& Raab, 2003). It is important to note that if a company has good sustainability management, its operating costs would be low and ultimately its efficiency will also improve in the long term (Bachoo et al., 2013).

*Corresponding author's email: qlkweh@uniten.edu.my 
Consistent with the government's aspiration in the Economic Transformation Programme (ETP) to achieve its developed status, this study considers a contemporary measure of financial performance which is multidimensional. In contrast to single-dimensional measures of corporate performance, data envelopment analysis (DEA), a mathematical-programming method that incorporates multiple variables (Cooper, Seiford, \& Tone, 2006), provides a comprehensive performance measure. Various attributes can be evaluated simultaneously to calculate an efficiency score for a decision-making unit (DMU). In other words, a holistic performance evaluation that provides aggregated activities information can be done via DEA (Homburg, 2001; Yeh, 1996). Taken together, this study examines the relationship between ESG and efficiency, which is considered in a holistic manner.

The paper proceeds as follows. The next section reviews prior studies, while the third section discusses methodology and data collection used in this study. The fourth section presents the empirical results. The final section concludes this study.

\section{The Impacts of ESG on Corporate Performance in Malaysia}

Under the fast-changing business environment, companies without SRI may face some problems such as decline in reputation, loss of customer loyalty and sales, and loss of intellectual capital. In other words, good ESG performance may create intangible values through minimizing unnecessary costs and solving potential conflicts with stakeholders. Ultimately, such companies will enjoy continuous support from stakeholders like consumers and investors who value ESG in business. This means that top management of a company has to consider ESG when making business decision. The growing number of ESG reports is an example whereby companies incorporate ESG into business practices (Lee \& Saen, 2012).

The extant literature has examined the relationship between various aspects of ESG and firm performance. However, in this section, we only review studies that have been conducted in the Malaysian context. In order to highlight any gaps in which our study addresses, the focus of review is on (1) the scope of investigation, (2) sample used, (3) measurement of variables, and (4) the findings. While we only try to develop some trends here, a full list of studies reviewed is available in Table 1. The list is not exhaustive; however, we believe that we have covered a sufficient number of important journal articles. 
Table 1 Prior studies examining the association between ESG and FP in Malaysia (FP influences ESG)

\begin{tabular}{|c|c|c|c|c|c|c|}
\hline No & Author(s) & Sample & $\begin{array}{c}\text { ESG } \\
\text { component }\end{array}$ & ESG measure & $\begin{array}{c}\text { Firm } \\
\text { performance }\end{array}$ & Findings \\
\hline 1 & $\begin{array}{l}\text { Amran et } \\
\text { al. (2012) }\end{array}$ & $\begin{array}{c}100 \text { PLCs (35 } \\
\text { members of } \\
\text { sustainability } \\
\text { networks; } 65 \\
\text { conveniently selected } \\
\text { from several } \\
\text { industries) }\end{array}$ & Environment & 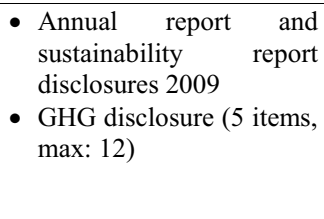 & $\begin{array}{l}\text { Lag return on } \\
\text { assets }\end{array}$ & $\begin{array}{c}\text { Positive and } \\
\text { significant }\end{array}$ \\
\hline 2 & $\begin{array}{l}\text { Esa \& } \\
\text { Mohd } \\
\text { Ghazali } \\
(2012)\end{array}$ & 27 GLCs & CSR & $\begin{array}{l}\text { - Annual report disclosures } \\
2005 \text { \& } 2007 \\
\text { - Categories: human } \\
\text { resource, value-added, } \\
\text { environment, community, } \\
\text { \& product } \\
\text { - } 21 \text { items (1,0 scoring) }\end{array}$ & $\begin{array}{l}\text { Profit before } \\
\text { tax over total } \\
\text { assets }\end{array}$ & $\begin{array}{l}\text { Positive but } \\
\text { not significant }\end{array}$ \\
\hline 3 & $\begin{array}{l}\text { Othman et } \\
\text { al. }(2011)\end{array}$ & $\begin{array}{l}117 \text { PLCs from } \\
\text { industrial products, } \\
\text { properties, and } \\
\text { plantation sectors } \\
\text { (random) }\end{array}$ & ESG & $\begin{array}{l}\text { - Annual report disclosures } \\
2007 \quad \text { Categories: citizenship } \\
\text { - } \\
\text { (community g } \\
\text { environment), workplace, } \\
\text { and governance } \\
\text { (marketplace) } \\
\text { - } 40 \text { items (0-2 scale; max: } \\
80)\end{array}$ & $\begin{array}{l}\text { Profit after tax } \\
\text { over total } \\
\text { assets (control } \\
\text { variable) }\end{array}$ & $\begin{array}{c}\text { Positive and } \\
\text { significant }\end{array}$ \\
\hline 4 & $\begin{array}{l}\text { Sheikh Abu } \\
\text { Bakar \& } \\
\text { Ameer } \\
(2011)\end{array}$ & $\begin{array}{c}333 \text { PLCs }(6 \\
\text { sectors); only } 131 \\
\text { reporting companies } \\
\text { selected for further } \\
\text { analysis }\end{array}$ & CSR & $\begin{array}{l}\text { - Annual report disclosures } \\
2007 \\
\text { - Readability score - using } \\
\text { Flesh Reading Ease and } \\
\text { Bullfighter composite } \\
\text { index }\end{array}$ & $\begin{array}{ll}\text { - } & \text { Earnings } \\
\text { before } \\
\text { tax over } \\
\text { total } \\
\text { assets } \\
\text { - } \quad \text { Tobin's q } \\
\end{array}$ & $\begin{array}{c}\text { Positive and } \\
\text { significant }\end{array}$ \\
\hline 5 & $\begin{array}{l}\text { Wan Abd } \\
\text { Rahman et } \\
\text { al. }(2011)\end{array}$ & 44 GLCs & CSR & $\begin{array}{l}\text { - Annual report disclosures } \\
2005-2006 \\
\text { - Categories: human } \\
\text { resource, community, } \\
\text { marketplace, \& } \\
\text { environment } \\
\text { - } 16 \text { items (Number of } \\
\text { sentences) }\end{array}$ & $\begin{array}{l}\text { Net profit } \\
\text { after tax over } \\
\text { sales }\end{array}$ & $\begin{array}{l}\text { Positive but } \\
\text { not significant }\end{array}$ \\
\hline 6 & $\begin{array}{c}\text { Abd. } \\
\text { Rahman et } \\
\text { al. (2009) }\end{array}$ & $\begin{array}{l}\text { Top } 56 \text { disclosing } \\
\text { PLCs }\end{array}$ & Environment & $\begin{array}{l}\text { - Annual report disclosures } \\
2006 \\
\text { - Classified into detailed, } \\
\text { superficial, and both }\end{array}$ & $\begin{array}{l}\text { Net income } \\
\text { over assets } \\
\text { (high, } \\
\text { medium, and } \\
\text { low) }\end{array}$ & Not significant \\
\hline 7 & $\begin{array}{l}\text { Elijido-Ten } \\
\text { (2009) }\end{array}$ & $\begin{array}{l}40 \text { companies } \\
\text { reported on the } \\
\text { environment ( } 79 \\
\text { firm-year } \\
\text { observations) } \\
\end{array}$ & Environment & $\begin{array}{l}\text { - Annual report disclosures } \\
2000-2001 \\
\text { - } 19 \text { items (0-3 scoring; } \\
\text { number of sentences })\end{array}$ & $\begin{array}{l}\text { Average } \\
\text { return on } \\
\text { assets }\end{array}$ & $\begin{array}{l}\text { Negative but } \\
\text { not significant }\end{array}$ \\
\hline 8 & $\begin{array}{l}\text { Heaney } \\
(2009)\end{array}$ & 161 PLCs & Governance & $\begin{array}{l}\text { - Year of analysis: 2000- } \\
2002 \\
\text { - Board size } \\
\text { - Board independence }\end{array}$ & $\begin{array}{l}\text { Book to } \\
\text { market ratio }\end{array}$ & $\begin{array}{l}\text { - Insignificant } \\
\text { - Board size: } \\
\text { Year 2000 } \\
(+) \\
\end{array}$ \\
\hline 9 & $\begin{array}{l}\text { Muhamad } \\
\text { et al. } \\
(2009)\end{array}$ & 159 PLCs (random) & Governance & $\begin{array}{l}\text { - Annual report disclosures } \\
2006 \\
\text { - Disclosure index (1,0 } \\
\text { scoring) }\end{array}$ & $\begin{array}{l}\text { Net profit } \\
\text { margin }\end{array}$ & $\begin{array}{c}\text { Positive but } \\
\text { not significant }\end{array}$ \\
\hline
\end{tabular}


Table 1 Prior studies examining the association between ESG and FP in Malaysia (FP influences ESG)

\begin{tabular}{|c|c|c|c|c|c|c|}
\hline No & Author(s) & Sample & $\begin{array}{c}\text { ESG } \\
\text { component }\end{array}$ & ESG measure & $\begin{array}{c}\text { Firm } \\
\text { performance }\end{array}$ & Findings \\
\hline 10 & $\begin{array}{l}\text { Othman et } \\
\text { al. (2009) }\end{array}$ & $\begin{array}{l}\text { Top } 56 \text { Shari'ah- } \\
\text { approved PLCs }\end{array}$ & $\begin{array}{l}\text { (Islamic) } \\
\text { ESG }\end{array}$ & $\begin{array}{l}\text { - Annual report disclosures } \\
\text { 2004-2006 } \\
\text { - Categories: Finance \& } \\
\text { investments, products and } \\
\text { services, employees, } \\
\text { society, environment, \& } \\
\text { corporate governance } \\
\text { - } 43 \text { items (1,0 scoring) }\end{array}$ & $\begin{array}{l}\text { Profit before } \\
\text { tax }\end{array}$ & $\begin{array}{c}\text { Positive but } \\
\text { not significant }\end{array}$ \\
\hline 11 & $\begin{array}{l}\text { Shakir } \\
(2008)\end{array}$ & $\begin{array}{l}81 \text { PLCs from the } \\
\text { properties sector }\end{array}$ & Governance & $\begin{array}{l}\text { - Year of analysis: } 1999 \text { - } \\
2005 \\
\text { - Block ownership }(\geq 5 \%)\end{array}$ & $\begin{array}{l}\text { - Tobin's q } \\
\text { - Market } \\
\text { value }\end{array}$ & $\begin{array}{l}\text { - } \text { Tobin's q (-) } \\
\text { - Market } \\
\text { value }(+)\end{array}$ \\
\hline 12 & $\begin{array}{l}\text { Amran et } \\
\text { al. (2007) }\end{array}$ & $\begin{array}{c}\text { Top } 100 \text { companies } \\
\text { (PLCs) }\end{array}$ & Social & $\begin{array}{l}\text { - Amount of cash donation } \\
\text { for } 2004 \\
\text { - } 65 \text { companies - collected } \\
\text { from a previous study; } 35 \\
-\quad \text { from annual } \\
\text { report/website }\end{array}$ & $\begin{array}{l}\text { Profit before } \\
\text { tax }\end{array}$ & $\begin{array}{l}\text { Positive but } \\
\text { not significant }\end{array}$ \\
\hline 13 & $\begin{array}{l}\text { Mohamad } \\
\text { Ariff et al. } \\
(2007)\end{array}$ & $\begin{array}{l}95 \text { companies in the } \\
\text { Corporate } \\
\text { Governance rating }\end{array}$ & Governance & $\begin{array}{l}\text { - Classified into top and } \\
\text { bottom } 50 \%\end{array}$ & $\begin{array}{l}\text { Net profit } \\
\text { margin }\end{array}$ & $\begin{array}{c}\text { Positive but } \\
\text { not significant }\end{array}$ \\
\hline 14 & $\begin{array}{c}\text { Mohd } \\
\text { Ghazali } \\
(2007)\end{array}$ & $\begin{array}{l}87 \text { Composite Index } \\
\text { non-financial } \\
\text { companies }\end{array}$ & CSR & $\begin{array}{l}\text { - Annual report disclosures } \\
2001 \\
\text { - } 22 \text { items }(1,0 \text { scoring })\end{array}$ & $\begin{array}{l}\text { Profit before } \\
\text { tax over total } \\
\text { assets }\end{array}$ & $\begin{array}{c}\text { Positive but } \\
\text { not significant }\end{array}$ \\
\hline 15 & $\begin{array}{l}\text { Haniffa \& } \\
\text { Cooke } \\
(2005)\end{array}$ & $\begin{array}{l}139 \text { non-financial } \\
\text { PLCs (stratified) }\end{array}$ & CSR & $\begin{array}{l}\text { - Annual report disclosures } \\
1996 \text { and } 2002 \\
\text { - Categories: community, } \\
\text { environmental, } \\
\text { employee, product/ } \\
\text { service, \& value-added } \\
\text { - } 41 \text { items (1,0 scoring; } \\
\text { number of words) }\end{array}$ & $\begin{array}{c}\text { Earnings after } \\
\text { tax over total } \\
\text { equity (control } \\
\text { variable) }\end{array}$ & $\begin{array}{c}\text { Positive } \\
\text { and } \\
\text { significant }\end{array}$ \\
\hline 16 & $\begin{array}{l}\text { Ahmad et } \\
\text { al. (2003) }\end{array}$ & $\begin{array}{c}\text { 299 PLCs } \\
\text { (randomly-selected) }\end{array}$ & Environment & $\begin{array}{l}\text { - Annual report disclosures } \\
1999 \\
\text { - Incidence (report/not) }\end{array}$ & $\begin{array}{l}\text { Profit over } \\
\text { assets }\end{array}$ & $\begin{array}{c}\text { Positive but } \\
\text { not significant }\end{array}$ \\
\hline
\end{tabular}

Overall, based on our review, the findings on the relationship between ESG (or its components) and firm performance have been inconclusive. However, the large majority found the influence to be insignificant (bin Abd. Rahman, binti Yusoff, \& binti Wan Mohamed, 2009; Esa \& Anum Mohd Ghazali, 2012; Hawani Wan Abd Rahman, Mohamed Zain, \& Hanim Yaakop Yahaya Al-Haj, 2011). The same situation is said to happen for studies examining the impact of ESG on firm performance. For example, (Koe Hwee Nga, 2009) found that ISO $14000^{1}$ adopters have significantly better ROE than the non-adopters. However, the same finding was not observed when using sales and market capitalisation as the proxies for financial performance. Additionally, Ponnu \& Ramthandin (2008) found that companies with higher corporate governance rating have better ROE only when weighted rating score was used (but not when using the raw score) and the rating had no impact on the holding period return of the sample companies. This implies that different

\footnotetext{
${ }^{1}$ ISO 14000 is a series of environmental management standards developed and published by the International Organization for Standardization (ISO) for organizations. The ISO 14000 standards provide a guideline or framework for organizations that need to systematize and improve their environmental management efforts.
} 
measure could lead to different findings. Thus, the inconsistent findings offered by the previous studies warrant another separate research to be conducted.

Theories that have been applied to support this proportion "by engaging in ESG initiatives, companies can improve their financial performance" include good management theory (Fauzi, 2009), porter hypothesis (Wagner, Schaltegger, \& Wehrmeyer, 2001), stakeholder theory (Saleh, Zulkifli, \& Muhamad, 2011), and stewardship theory (Koe Hwee Nga, 2009). Therefore, we develop the following alternate hypothesis:

Hypothesis: Environmental, Social and Governance have impacts on corporate performance.

\section{DESCRIPTION OF METHODOLOGY}

\section{Data Collection}

The data for ESG is based on the Sustainalytics ESG Research data available in the Bloomberg made by companies in their annual reports, stand-alone reports, and websites. We choose secondary data for several reasons. Firstly, the data is easily accessible from databases. Secondly, we believe that companies would disclose information should they perceive the information is important for the stakeholders to make decisions. In this regard, we assume that disclosure, to a large extent, equates the actual practice. Thirdly, the use of secondary data is consistent with the previous studies in this area (Amran, Ooi, Nejati, Zulkafli, \& Lim, 2012; Esa \& Anum Mohd Ghazali, 2012; Hawani Wan Abd Rahman et al., 2011; Ponnu \& Ramthandin, 2008; Saleh et al., 2011).

After removing observations with missing data, we have a final sample of 387 firm-year observations for analyses. Our sample companies are GLCs in Malaysia, covering the period from 2006-2012. This study does not rely on the list of GLCs published on The Putrajaya Committee on GLC High Performance (PCG) website as it is outdated at the time of this writing. We identify GLCs as Malaysian listed companies with $20 \%$ equity shares held by GLICs (Zin \& Sulaiman, 2011).

Our study focus on the impacts of ESG on firm performance of Malaysian GLCs. Prior literature in Malaysia has largely focused on public listed companies in general. Esa \& Anum Mohd Ghazali (2012) and Hawani Wan Abd Rahman et al. (2011) examined the association of ESG and firm performance among GLCs, however, the number of sample is rather small with 27 and 44 companies, respectively. Using GLCs as the focus is essential since we expect these companies to be more proactive in ESG initiatives than their counterparts, as a result of various Government initiatives on ESG.

\section{Methodology}

To provide answers to our research questions, we apply a two-stage approach. In the first (1) stage, we estimate efficiency performance of our sample companies using DEA. In the second (2) stage, this study performs regression analysis to examine the impact of ESG on efficiency performance. 


\section{Performance Measure: Data envelopment analysis (DEA)}

DEA, a widely used linear-programming-based composite tool, is developed by Charnes, Cooper, \& Rhodes (1978) and extended by Banker, Charnes, \& Cooper (1984). DEA, a mathematical technique comparing multiple inputs and outputs of decision-making units (DMUs) for measuring relative DMUs' efficiency, allows the identification of benchmarking. Instead of using merely unidimensional ratios and other individual financial variables, IC indicators such as human capital and structural capital can be accommodated so that possible interactions between them can be captured to derive efficiency scores using DEA. Moreover, DEA approach provides added information (Feroz et al., 2003).

\section{Truncated Regression Model}

Note that efficiency scores range from zero to one. As the truncated regression technique is able to offset the bias involved in estimating such parameters, this study adopts truncated regression proposed by Simar \& Wilson (2007) to examine the impact of exogenous factors on operating efficiency and ESG score. In the regression analysis, we will run truncated regression for Equation (2). The following regression models are estimated:

$$
E F F_{i t}=\alpha_{0}+\alpha_{1} E N V_{i t}+\alpha_{2} S O C_{i t}+\alpha_{3} G O V_{i t}+\alpha_{4} F S I Z E_{i t}+\alpha_{5} F L E V_{i t}+\alpha_{6} M T B_{i t}+\alpha_{7} O C F_{i t}+\varepsilon
$$

where

$E F F_{i t}=$ The efficiency score in year $t$.

$E N V_{i t}=$ The percentage of environmental-related disclosures of firm $i$ at period $t$.

$S O C_{i t}=$ The percentage of social-related disclosures of firm $i$ at period $t$.

$G O V_{i t}=$ The percentage of governance-related disclosure of firm $i$ at period $t$.

$F S I Z E_{i t}=$ The natural logarithm of total assets of firm $i$ at period $t$.

$F L E V_{i t}=$ The ratio of the sum of short-term and long-term borrowings to total assets of firm $i$ at period $t$.

$M T B_{i t}=$ The ratio of market value to book value of firm $i$ at period $t$.

$O C F_{i t}=$ The ratio of operating cash flow to total assets of firm $i$ at period $t$.

\section{EMPIRICAL RESULTS}

Table 2 presents the descriptive statistics of dependent variable and explanatory variables. The average of environmental score (ENV) in our sample is about 1.484. The mean of social score (SOC) is 2.863, and the mean of governance score (GOV) is about 34.606. Among the three pillar of ESG, governance seems to have the largest amount value, followed by social aspects. This suggests that the firms disclosed GOV information more than SOC and ENV. It is also noteworthy that the standard deviation of GOV and SOC are relatively high as compared to the ENV. Meanwhile, the mean firm size is approximately 9.185, while the mean of firm leverage is about 0.229 . 
Table 2 Descriptive Statistics

\begin{tabular}{lccccc}
\hline Variable & Mean & Median & Maximum & Minimum & Std. Dev \\
\hline EFF & 0.541 & 0.472 & 1 & 0.020 & 0.336 \\
ESG & 54.475 & 30.165 & 100.000 & 9.211 & 40.668 \\
ENV & 1.484 & 0 & 49.612 & 0 & 5.554 \\
SOC & 2.863 & 0 & 60.938 & 0 & 9.166 \\
GOV & 34.606 & 48.214 & 73.214 & 0.103 & 21.829 \\
FSIZE & 9.185 & 9.227 & 13.369 & 4.633 & 1.667 \\
FLEV & 0.229 & 0.210 & 0.659 & 0 & 0.166 \\
MTB & 3.967 & 1.796 & 157.392 & 0.303 & 10.352 \\
OCF & 0.092 & 0.062 & 0.752 & -0.117 & 0.116 \\
\hline
\end{tabular}

Table 3 reports the Pearson correlation coefficients in a two-tailed setting. GOV is significantly and positively related to efficiency (EFF). This means that firms' performance is increased when the firms disclose the GOV information. Meanwhile, we only find a significantly positive correlation between governance (GOV) and ESG. From this study, we can see among the three pillars of ESG, firms are most likely to disclose GOV information because it can enhance the efficiency of the firm performance. Other correlation coefficients are all lower than 0.5 . Besides, the maximum value of untabulated variance inflation factors (VIF) is about 2.0. These results suggest that there is no multicollinearity problem for multivariate analysis.

Table 3 Correlation Matrix

\begin{tabular}{|c|c|c|c|c|c|c|c|c|c|}
\hline Probability & EFF & ESG & ENV & SOC & GOV & FSIZE & FLEV & MTB & $\begin{array}{c}\mathrm{OC} \\
\mathrm{F}\end{array}$ \\
\hline EFF & 1 & & & & & & & & \\
\hline ESG & 0.0216 & 1 & & & & & & & \\
\hline ENV & -0.0037 & $\begin{array}{l}- \\
0.1478 * * *\end{array}$ & 1 & & & & & & \\
\hline SOC & -0.0136 & - & $0.8862 * * *$ & 1 & & & & & \\
\hline GOV & $\begin{array}{l}0.1185 * \\
*\end{array}$ & $0.1925^{* * *}$ & -0.0720 & $-0.0894 *$ & 1 & & & & \\
\hline FSIZE & $\overline{0.0968 *}$ & $0.0945^{*}$ & 0.0385 & $0.0857 *$ & $0.4354 * * *$ & 1 & & & \\
\hline FLEV & $\begin{array}{l}- \\
0.2367 * \\
* *\end{array}$ & $-0.0974 * *$ & 0.0352 & 0.0262 & $-0.0956 * *$ & $0.1952 * * *$ & 1 & & \\
\hline MTB & $\begin{array}{l}0.2341 * \\
* *\end{array}$ & $0.1399 * * *$ & $0.1992 * * *$ & $0.1121 * *$ & -0.0524 & - & 0.0467 & 1 & \\
\hline $\mathrm{OCF}$ & $\begin{array}{l}0.3574 * \\
* *\end{array}$ & 0.07705 & $0.2297 * * *$ & $0.1236 * *$ & $-0^{-} 1676^{* * *}$ & - & $\begin{array}{l}- \\
0.1327 * \\
*\end{array}$ & $0.6252 * * *$ & 1 \\
\hline
\end{tabular}

*, ** and *** are statistical significances at the $10 \%, 5 \%$ and $1 \%$ levels, respectively.

Table 4 reports the outcomes of the regression analysis. The models are significant at the 0.01 significance level. The result shows that environment (ENV) has a negative relationship with efficiency (EFF) and the coefficient is significant. While previous studies that focus on environment issues find a positive results between environment and firm efficiency (Al-Najjar \& Anfimiadou, 2012; Derwall, 2007; Sinkin, Wright, \& Burnett, 2008), this study argues that the focus of GLCs could be the reason for the negative association. 
Table 4 Regression Results (Dependent variable:EFF)

\begin{tabular}{llllll}
\hline & \multicolumn{2}{c}{ OLS } & & \multicolumn{2}{c}{ Tobit } \\
\cline { 2 - 3 } \cline { 5 - 5 } Variable & Coefficient & Prob. & & Coefficient & Prob. \\
\hline C & $0.3323^{* *}$ & 0.0194 & & $0.2488^{* * *}$ & 0.0005 \\
ENV & $-0.0096^{*}$ & 0.0772 & & $-0.0154^{*}$ & 0.0641 \\
SOC & 0.0030 & 0.4500 & & 0.0053 & 0.3592 \\
GOV & -0.0596 & 0.5218 & & $-0.0457^{* * *}$ & 0.0003 \\
FSIZE & $0.0245^{*}$ & 0.0810 & & 0.0363 & 0.5561 \\
FLEV & $-0.4153^{* * *}$ & 0.0027 & & $-0.5392^{* * *}$ & 0.0004 \\
MTB & 0.0015 & 0.4792 & & 0.0152 & 0.3959 \\
OCF & $1.0845^{* * *}$ & 0.0000 & & $1.1873^{* * *}$ & 0.0000 \\
& & & & \\
Adjusted R-squared & 0.1697 & & & \\
F-statistic & $12.2726^{* * *}$ & & & \\
Log likelihood & & & & \\
\hline * Statistical significance at the $10 \%$ level. & & & \\
** Statistical significance at the 5\% level. & & & \\
** Statistical significance at the $1 \%$ level. & & & &
\end{tabular}

Specifically, the role of ESG in GLCs can be different in the sense that government may lead and promote more spending on protecting the environment without considering the consequence of the high spending on ENV on its firm performance. The coefficient of social (SOC) is positive and insignificant; this finding is similar with Filbeck, Gorman, \& Zhao (2009). For the governance aspect, Statman \& Glushkov (2009) and Core, Guay, \& Rusticus (2006) find that this aspect does not affect firm performance. Meanwhile, this study shows the coefficients of governance (GOV) are negative but only significant in the Tobin regression. These suggest that the SOC and GOV of ESG generally do not enhance firm performance. Firm size (FSIZE), market to book (MTB) and operating cash flow (OCF) are positively related to EFF but the coefficient of MTB is insignificant. However, firm leverage (FLEV) has a significantly negative association with efficiency.

\section{DISCUSSION}

This study may create greater awareness on ESG practices among companies in Malaysia. Through the use of GLCs as our sample, we may show that Malaysia government plays a leading role in leading the corporate sector to invest in ESG for sustainable long-term performance. The information obtained from this study provides insights to ponder on the effectiveness of the government initiative in launching the Government-linked Companies Transformation Programme (GLCTP) in May 2004. This study covers up to the final phase of the 10-year plan of GLCTP. By promoting investment in ESG, Malaysia will be able to attract more foreign direct investments or investors who value sustainability in business. This supports the government's first idea out of ten ideas contained in the 10th Malaysia Plan (2011-2015) which is internally driven, externally aware. This awareness will subsequently promote growth in private sector investment. This study is very important to many stakeholders in helping them improve the living standard and quality of life in many ways (from the perspective of environmental, social, and governance) as aspirated in the 10th Malaysia Plan through income and capacity building programmes, strengthening the social safety net and addressing the needs of the disadvantaged groups. 


\section{CONCLUSION}

We explore the impact of ESG on efficiency using GLCs in Malaysia from year 2006 to 2012. This study obtains data on the ESG disclosure level from the Sustainalytics ESG Research data available in the Bloomberg. The study finds that GLCs focus more on governance disclosures, followed by social and environmental disclosures. The regression analyses show that governance is positively associated with firm efficiency, but social and environmental factors have no similar effect. In summary, this study provides an insight on the limited literature on ESG and informs the relevant stakeholders on the important ESG components for financial and investment decisions.

There are limitations in this study that we need to acknowledge. First, the sample of companies comes from GLCs, leaving us unable to make general conclusions to all companies in Malaysia. It would be interesting to carry out a similar study that tests other companies in Malaysia to strengthen the results of this study. Second, the Sustainalytics ESG Research is used to test the ESG reporting, suggesting that future studies may utilise alternative ESG dataset. In other words, a comparison study can be performed in future research.

\section{ACKNOWLEDGEMENTS}

The researchers wish to thank the Ministry of Higher Education Malaysia (MOHE) for the research grant received to undertake this research (FRGS/1/2014/SS05/UNITEN/03/4).

\section{REFERENCES}

Al-Najjar, B., \& Anfimiadou, A. (2012). Environmental policies and firm value. Business Strategy and the Environment, 21(1), 49-59.

Amran, A., Ooi, S. K., Nejati, M., Zulkafli, A. H., \& Lim, B. A. (2012). Relationship of firm attributes, ownership structure and business network on climate change efforts: evidence from Malaysia. International Journal of Sustainable Development \& World Ecology, 19(5), 406-414.

Arvidsson, S. (2010). Communication of corporate social responsibility: A study of the views of management teams in large companies. Journal of Business Ethics, 96(3), 339-354.

Bachoo, K., Tan, R., \& Wilson, M. (2013). Firm value and the quality of sustainability reporting in Australia. Australian Accounting Review, 23(1), 67-87.

Banker, R. D., Charnes, A., \& Cooper, W. W. (1984). Some models for the estimation of technical and scale inefficiencies in data envelopment analysis. Management Science, 30(9), 10781092. 
Bassen, A., \& Kovacs, A. M. M. (2008). Environmental, social and governance key performance indicators from a capital market perspective. Zeitschrift für Wirtschafts-und Unternehmensethik(9/2), 182-192.

Bebchuk, L. A., Cohen, A., \& Wang, C. C. (2013). Learning and the disappearing association between governance and returns. Journal of financial economics, 108(2), 323-348.

bin Abd. Rahman, S. A., binti Yusoff, R., \& binti Wan Mohamed, W. N. (2009). Environmental disclosure and financial performance: An empirical study of Malaysia, Thailand and Singapore. Social and Environmental Accountability Journal, 29(2), 46-58.

Charnes, A., Cooper, W. W., \& Rhodes, E. (1978). Measuring the efficiency of decision making units. European Journal of Operational Research, 2, 429-444.

Clark, G. L., Feiner, A., \& Viehs, M. (2015). From the stockholder to the stakeholder: How sustainability can drive financial outperformance. Available at SSRN 2508281.

Cooper, W. W., Seiford, L. M., \& Tone, K. (2006). Introduction to data envelopment analysis and its uses: with DEA-solver software and references: Springer Science \& Business Media.

Core, J. E., Guay, W. R., \& Rusticus, T. O. (2006). Does weak governance cause weak stock returns? An examination of firm operating performance and investors' expectations. The Journal of Finance, 61(2), 655-687.

Derwall, J. (2007). The economic virtues of SRI and CSR.

Esa, E., \& Anum Mohd Ghazali, N. (2012). Corporate social responsibility and corporate governance in Malaysian government-linked companies. Corporate Governance: The international journal of business in society, 12(3), 292-305.

Fauzi, H. (2009). The Determinants of the Relationship of Corporate Social Performance and Financial Performance: A Conceptual Framework. Issues in Social and Environmental Accounting, Forthcoming.

Feroz, E. H., Kim, S., \& Raab, R. L. (2003). Financial statement analysis: A data envelopment analysis approach. Journal of the Operational Research Society, 54(1), 48-58.

Filbeck, G., Gorman, R., \& Zhao, X. (2009). The "Best Corporate Citizens": Are They Good for Their Shareholders? Financial Review, 44(2), 239-262.

Hawani Wan Abd Rahman, N., Mohamed Zain, M., \& Hanim Yaakop Yahaya Al-Haj, N. (2011). CSR disclosures and its determinants: evidence from Malaysian government link companies. Social Responsibility Journal, 7(2), 181-201.

Homburg, C. (2001). Using data envelopment analysis to benchmark activities. International Journal of Production Economics, 73(1), 51-58. 
Ihlen, Ø. (2008). Mapping the environment for corporate social responsibility: Stakeholders, publics and the public sphere. Corporate Communications: An International Journal, 13(2), 135-146.

Koe Hwee Nga, J. (2009). The influence of ISO 14000 on firm performance. Social Responsibility Journal, 5(3), 408-422.

Lee, K.-H., \& Saen, R. F. (2012). Measuring corporate sustainability management: A data envelopment analysis approach. International Journal of Production Economics, 140(1), 219-226.

Ponnu, C. H., \& Ramthandin, S. (2008). Governance and performance: Publicly listed companies in Malaysia. Journal of Business Systems, Governance and Ethics, 3(1), 35-53.

Saleh, M., Zulkifli, N., \& Muhamad, R. (2011). Looking for evidence of the relationship between corporate social responsibility and corporate financial performance in an emerging market. Asia-Pacific Journal of Business Administration, 3(2), 165-190.

Servaes, H., \& Tamayo, A. (2013). The impact of corporate social responsibility on firm value: The role of customer awareness. management science, 59(5), 1045-1061.

Simar, L., \& Wilson, P. W. (2007). Estimation and inference in two-stage, semi-parametric models of production processes. Journal of Econometrics, 136(1), 31-64.

Sinkin, C., Wright, C. J., \& Burnett, R. D. (2008). Eco-efficiency and firm value. Journal of accounting and public policy, 27(2), 167-176.

Statman, M., \& Glushkov, D. (2009). The wages of social responsibility. Financial Analysts Journal, 65(4), 33-46.

Wagner, M., Schaltegger, S., \& Wehrmeyer, W. (2001). The relationship between the environmental and economic performance of firms. Greener Management International, 2001(34), 94-111.

Wang, W.-K., Lu, W.-M., Kweh, Q. L., \& Lai, H.-W. (2014). Does corporate social responsibility influence the corporate performance of the US telecommunications industry? Telecommunications Policy, 38(7), 580-591.

Yeh, Q.-J. (1996). The application of data envelopment analysis in conjunction with financial ratios for bank performance evaluation. Journal of the Operational Research Society, 980988.

Zin, N. M., \& Sulaiman, S. (2011). Government-linked Companies Blue Book (GLCs Blue Book) as a complement to Balanced Scorecard (BSC) in the Government-Linked Companies transformation program. Paper presented at the 2010 International Conference on Business and Economics Research. 